\title{
"Marketing environment and marketing management of universities in Ukraine: national and regional dominants"
}

\begin{tabular}{|c|c|}
\hline \multirow{5}{*}{ AUTHORS } & Yurii Petrunia (D) https://orcid.org/0000-0001-5933-4986 \\
\hline & Victor Chentsov (D https://orcid.org/0000-0002-1109-8168 \\
\hline & R https://publons.com/researcher/1875835/victor-v-chentsov/ \\
\hline & Norbert Życzyński (D https://orcid.org/0000-0003-0681-3072 \\
\hline & Vira Petrunia (D https://orcid.org/0000-0003-4697-9851 \\
\hline ARTICLE INFO & $\begin{array}{l}\text { Yurii Petrunia, Victor Chentsov, Norbert Życzyński and Vira Petrunia (2019). } \\
\text { Marketing environment and marketing management of universities in Ukraine: } \\
\text { national and regional dominants. Innovative Marketing , 15(1), 1-12. } \\
\text { doi:10.21511/im.15(1).2019.01 }\end{array}$ \\
\hline DOI & http://dx.doi.org/10.21511/im.15(1).2019.01 \\
\hline RELEASED ON & Tuesday, 05 February 2019 \\
\hline RECEIVED ON & Thursday, 03 January 2019 \\
\hline \multirow[t]{2}{*}{ ACCEPTED ON } & Tuesday, 22 January 2019 \\
\hline & $((c))_{E Y}$ \\
\hline LICENSE & $\begin{array}{l}\text { This work is licensed under a Creative Commons Attribution } 4.0 \text { International } \\
\text { License }\end{array}$ \\
\hline JOURNAL & "Innovative Marketing " \\
\hline ISSN PRINT & $1814-2427$ \\
\hline ISSN ONLINE & $1816-6326$ \\
\hline PUBLISHER & LLC "Consulting Publishing Company "Business Perspectives" \\
\hline FOUNDER & LLC "Consulting Publishing Company "Business Perspectives" \\
\hline
\end{tabular}

NUMBER OF REFERENCES

26

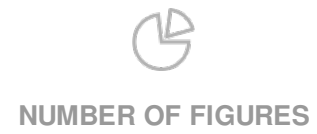

3
NUMBER OF TABLES

2

C The author(s) 2021. This publication is an open access article. 


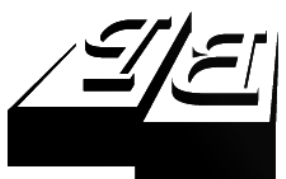

BUSINESS PERSPECTIVES

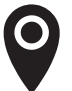

LLC “CPC "Business Perspectives" Hryhorii Skovoroda lane, 10, Sumy, 40022, Ukraine

www.businessperspectives.org

Received on: $3^{\text {rd }}$ of January, 2019 Accepted on: 22 $2^{\text {nd }}$ of January, 2019

(C) Limited Liability Company "Consulting Publishing Company "Business Perspectives", 2018

Yurii Petrunia, Doctor of Economics, Head, Department of Management of Foreign Economic Activity, University of Customs and Finance, Ukraine.

Victor Chentsov, Doctor of Public Management and Administration, First Vice-Rector, University of Customs and Finance, Ukraine.

Norbert Życzyński, Doctor of Business Administration, Faculty of Management, Rzeszow University of Technology, Poland.

Vira Petrunia, Ph.D. in Economics, Associate Professor, Department of Management of Foreign Economic Activity, University of Customs and Finance, Ukraine.
Yurii Petrunia (Ukraine), Victor Chentsov (Ukraine),

Norbert Życzyński (Poland), Vira Petrunia (Ukraine)

\section{MARKETING ENVIRONMENT AND MARKETING MANAGEMENT OF UNIVERSITIES IN UKRAINE: NATIONAL AND REGIONAL DOMINANTS}

\begin{abstract}
The marketing environment of universities' activities in Ukraine is changing dramatically. As a result, the system of chances and risks for universities is constantly changing. Therefore, timely detection of changes in the marketing environment and effective management ensure the competitiveness of the universities. The aim of the article is to identify the marketing environment dominants of the Ukrainian universities, as well as to assess the efficiency of marketing tools application in the system of universities' management. On the basis of statistical and primary data analyses, the higher education market in Ukraine both at the state and regional levels has been assessed and the university's dependence on market sources of funding has been substantiated. As the modern domains of the marketing environment of universities, changes in the distribution of state-funded places, the impact of external independent testing, and the in tensification of competition between universities are determined. The influence of external independent testing on structural intersegmental changes concerning the choice of specialties of universities' entrants is proved. The comparative characteristics of the marketing management tools in Ukrainian and Polish universities are considered. The obtained results outline the importance of strengthening the marketing orientation of management in universities.
\end{abstract}

\section{Keywords}

\section{JEL Classification}

higher education, university, management, marketing tools, marketing environment

\section{INTRODUCTION}

The management process of the university, as indeed for any other organization, is based on the continuous analysis of its activity in external and internal environment. In market-oriented organizations (Ukrainian universities are becoming similar to such organizations), an income, either fully or partially, is provided by their market (commercial) activity. The latter involves, above all, participation in competition, the ability to timely detect changes in the marketing environment and respond adequately to them.

Universities in Ukraine are subjects that provide higher education services that can be fee-paying (commercial) for entrants (in this case, the institution of higher education (IHE) acts as the subject of the educational services market) or can be for the entrant's budget transfer (free of charge). In Ukraine, universities compete with each other for both categories of entrants, thus, a mixed university funding system operates accordingly. 
However, on the one hand, the existing system of state financing of universities is imperfect, and, on the other hand, there is a steady tendency to reduce the share of expenditures on higher education in the general state budget expenditures of Ukraine. The latter, in particular, is one of the reasons for the growing dependence of universities on market sources of funding, on the efficiency of attracting the students to commercial education. In addition, there is a steady increase in competition in the market of higher education - both at the national and regional levels.

The analysis of the marketing environment of the university's activities is the basis for making adequate, timely and effective management decisions. Qualitative analysis, definition of trends and predictive assessments are the important tasks of top management of universities. The situation is worsened by the fact that the marketing environment of the institutions of higher education in Ukraine is hard to predict, difficult and not very favorable for universities. Thus, the search for quality marketing management solutions to ensure the competitiveness of universities is an extremely topical issue that becomes of great practical importance in modern conditions.

\section{LITERATURE REVIEW}

Analysis of researches suggests that the issues of the development of the market for higher education, marketing management of universities are not well-studied and often do not fall into the field of scientists.

Among the recent publications devoted to this problem, one can, in particular, highlight the article by Kollini (2016), in which the author argues that the purpose of universities cannot be regarded as an instrument of assistance to members of society in earning money. Accordingly, the state, above all, its government institutions, in determining the scale and order of funding the universities, are not able to go beyond the categories of gross domestic product, economic growth, career, wages, etc.

A number of research studies are devoted to the education and marketing activities of universities in Poland. Kwiek (2013) investigated the evolution of higher education in Poland from system expansion to system contraction. Kudła, StachowiakKudła, Polszakiewicz, and Boehlke (2014) studied the higher education competition in Poland and the quality of teaching and research. A systematic methodological approach to the study of the marketing environment of education was proposed by Hall (2007).

Boujen (2018) undertook an interesting study on the peculiarities of higher education in the "digital age".
A number of authors see a promising future for universities in the development of on-line education, which in fact means the development of new products by universities (P. Aithal \& S. Aithal, 2016; Northey et al., 2015; Prasad \& Aithal, 2017; Tienhaara, Lyytinen, \& Kivistö, 2016). Certainly, digital technologies and the formation of a "digital society" make significant changes both in the external (marketing) and in the internal environment of the activities of modern universities and should be reflected accordingly in the management systems of universities and activities of their managers.

Shevchenko (2016), in the context of the analysis of modern university management in Ukraine and in the world, concluded about the importance of "scanning the educational environment and the positioning of the university in it".

A number of authors drew special attention to such a factor in the functioning of universities as the role of the state in the market of higher education, as well as on the issues of centralization and decentralization in the field of higher education (Babichev, 2017; Sihaieva, 2017).

The factors selected by the students of the subjects of higher education offerings also found their place in modern scientific research (Shah, Sid Nair, \& Bennett 2013; Orindaru, 2016).

Interaction of external and internal environment of universities was considered by Agyemang and Broadbent (2015). The main stages of the evolution 
of educational marketing were reflected by Manea and Purcaru (2017).

The marketing issue of higher education is reviewed annually by practitioners and researchers at the special conferences of the American Marketing Association (n.d.), HUMANE (Heads of University Management and Administration Network Europe) and ESMU (European Center for Strategic Management of Universities) are focusing on the issues of improving the management in European universities, which, in particular, are under the strategic partnership with EFMD (European Foundation for Management Development), implement benchmarking programs (European Foundation for Management Development, n.d.).

It should be noted that the creation and functioning of the Ukrainian Center for Educational Quality Assessment, which is engaged in the organization of independent testing of university entrants, has created opportunities for researchers to use new important statistical information on education in Ukraine, in particular, to increase the level of forecasting of the capacity of the market of higher education, including different segments (Український Центр оцінювання якості освіти [Ukrainskyi tsentr otsiniuvania yakosti osvity], n.d.).

In general, there is little research work on educational marketing in general, and this is a new area of research (Manea \& Purcaru, 2017).

So, it is necessary to study the factors that determine the state of the marketing environment of the universities - both in the aspect of current and in the perspective of long-term influence. Also, the interesting question is the future role of technology in relation to the depth and extent of their transformational influence on the market of higher education, the system of university services, etc.

\section{METHODS}

In the course of the study, the authors used the methods of systematic analysis of the components of university marketing environment in Ukraine, the methods of statistical analysis of the dynamics of the participation of entrants in external inde- pendent testing, followed by the construction of its graphical interpretation, the methods of generalization and systematization of statistical and primary information on the potential capacity of individual segments of applicants in Ukraine, methods of competitive positions comparing with the use of graphic illustration.

The purpose of the article is to study and assess the dominants of the marketing environment of universities in Ukraine, as well as to substantiate the necessity and peculiarities of application of marketing tools in the management of universities.

\section{RESULTS}

The positions of universities in the market of educational services, their competitiveness and prospects depend on a number of factors of external and internal origin. Among the components of the marketing environment of universities' activity in Ukraine, in our opinion, the factors of capacity of the market of higher education and state regulation, state policy in the field of higher education are of key importance in today's conditions.

Data from Table 1 indicate that in the framework of the national dimension of the state and the market of higher education in Ukraine, there is a tendency towards a decrease in almost all key indicators in recent years: the share of the state budget expenditure on financing the higher education - by $20 \%$; the total number of students - by $3.3 \%$; the number of undergraduate students - by $10 \%$; the number of students studying by state order - by $6.3 \%$, etc. Two hundred eighty-nine universities, academies and institutes (IHE of the III and IV accreditation levels) are represented in the higher education market of Ukraine, of which $68.9 \%$ are public, $4.5 \%$ are communal, $26.6 \%$ are private.

The capacity of the higher education market in Ukraine is influenced by a number of factors: demographic situation; income of people; ability of entrants to pass the external independent testing (EIT); state conditions (rules) for admission to IHE; intention of parents and entrants to choose the country of higher education; state policy on the total number and structure of budget places in state institutions of higher education (IHE), etc. 
Table 1. Main indicators of higher education in Ukraine

Source: Developed by the authors on the basis of State Statistics Service of Ukraine (2018).

\begin{tabular}{|c|c|c|c|}
\hline Indicators & 2015 & 2016 & 2017 \\
\hline $\begin{array}{l}\text { Expenditure on higher education (\% of total expenditures of the } \\
\text { consolidated budget of the state) }\end{array}$ & 4.6 & 4.2 & 3.7 \\
\hline Number of students per 10 thousand population & 322 & 321 & 314 \\
\hline Number of undergraduate students & 890,277 & 855,683 & 800,450 \\
\hline Number of IHE of the III and IV accreditation levels & 288 & 287 & 289 \\
\hline Number of students in IHE of the III and IV accreditation levels & $1,375,160$ & $1,369,432$ & $1,329,964$ \\
\hline Number of admitted to IHE of the III and IV accreditation levels & 259,904 & 253,217 & 264,448 \\
\hline \multicolumn{4}{|c|}{ Students who study under a state order } \\
\hline Total & 649,225 & 652,935 & 608,625 \\
\hline Percentage, \% & 47.2 & 47 & 45.8 \\
\hline \multicolumn{4}{|c|}{ Students who study on a contract basis (percentage, \%) } \\
\hline Local governments & 1.1 & 0.9 & 1.0 \\
\hline Legal entities & 0.7 & 0.7 & 0.5 \\
\hline Individuals & 51.0 & 50.7 & 52.7 \\
\hline
\end{tabular}

The demographic situation after a long-term negative trend for the universities has the signs of stabilization. With the GDP growth in the country, there is a certain increase in incomes of working population. Regarding the activity of regulatory institutes, the state is increasingly using the EIT tool to regulate the conditions for admission to IHE and the distribution of state orders among IHE of Ukraine.

Firstly, the state in recent years has fundamentally changed the order of distribution of budget places (respectively, funding) among IHE. The Ministry of Education and Science of Ukraine resorted to the principle of distribution of government-defined budget places between IHE on the basis of the entrants' results of EIT, according to which "a budget place goes to IHE together with a particular entrant". That is, budget places for IHE are created by entrants with the best results of the EIT. At first glance, such a decision is a logical idea: the higher the results of the EIT, the more budget preferences the entrants receive from the state, for which the state funding is received by the relevant IHE.

However, the following question arises: Does such rather a simple scheme consider everything correctly and fairly? Let's try to closely and objectively analyze, first of all, by what means the entrants achieve some forms of EIT indicators.

There are grounds to state that the individual outcomes of the EIT reflect the ability and endeavors of the student. But, in addition, they also reflect such factors as: the level (potential) of a particular school (and this influence is confirmed by the analytical and statistical materials of the Ukrainian Center for Educational Quality Assessment - by geography, by the status of EIT (Український центр оцінювання якості освіти [Ukrainskyi tsentr otsiniuvania yakosti osvity], n.d.); opportunities for parents to recruit and fund tutors; the level of parenting available for tutors. The question arises: what, in general, is more in the results of the external independent testing - internal (personal - abilities, efforts, etc.) or external (level of school, financial and organizational capabilities of parents, etc.)? It is necessary to pay attention also to the fact that the established system of providing budget places for entrants absolutely does not consider the level of income, the material condition of families. The difference in a few (and often even less) points on the results of the EIT can provide a financial advantage for the state of a rich family and deprive of it a low-income family. In addition, the specified order of distribution of budget places is not focused on the necessity of the first consideration of the peculiarities of regional labor markets, mitigation of differentiation in the conditions of activity of regional and metropolitan IHE. That is, in our opinion, there is a problem, and we need to continue the work on finding the ways to improve the system of distribution of budget places between the institutions of higher education.

Secondly, the system of the EIT has become one of the main factors that correct the formation of segments of entrants to enter this or that specialty. 
In our opinion, the system of the use of the EIT significantly changed the structure of demand for higher education in one or another specialty. Thus, one of the tendencies was a constant decrease in the number of entrants that pass the external independent testing in mathematics. As a result of the situation when centralized determination of sets of certificates of the EIT (subjects) is necessary for admission to certain specialties, institutions of higher education face the fact of reducing the capacity of the respective segments - the number of applicants enrolled in the corresponding specialty. These segments are associated with a sufficiently large group of specialties, where the availability of a math certificate is compulsory for participation in the entrance examination.

Thus, in 2013, the number of applicants enrolled in the EIT in mathematics was 197.5 thousand people, in 2016, this figure fell to 132.2 thousand people, in 2017, it was 113.1 thousand people (Figure 1).

In 2018 , the total number of registered for participation in the external independent testing was 335.7 thousand people. For the mathematics exam, 112.0 thousand people were registered, or $33.4 \%$. In 2018, the actual participation of entrants in the independent testing of mathematics was $95.1 \%$ of the registered number, $17.6 \%$ of applicants (from registered) did not exceed the threshold of the established minimum level (in 2013, this figure was approximately 9\%). Eventually, on the basis of the independent testing of mathematics, 86.7 thousand people were eligible to take part in the competition for admission to those specialties, which provided for the presentation of a certificate in mathematics. For comparison, in 2016, there were 104.8 thousand of such persons (Український центр оцінювання якості освіти [Ukrainskyi tsentr otsiniuvania yakosti osvity], n.d.). Such situation, of course, affects those IHE that work in the segments of specialties, for entry to which the EIT certificate in mathematics is required. And the greater the proportion of such specialties in the general spectrum of specialties, which are being trained in a particular IHE, the stronger is the influence of this factor.

The choice of subjects by the entrants for passing the external independent testing is one of the manifestations of the so-called "behavioral factors" of the subjects of demand. These same factors are manifested in the vibration of vision, first of all, of parents of entrants, "perspective" of a particular specialty. Parents of entrants represent the subjects of demand for educational services, parents are quite influential participants in the process of choosing an IHE and specialty. The practical experience of the authors of the article on the management of universities suggests that often the "vision of the parents" is not based on sufficient depth of assessment of the current and prospective situation on the labor market, their views reflect the asymmetry of information and factors of subjective and psychological nature. Over the past 10 years, there has been a lot of periodic splashes in increasing attention to some specialties and reducing interest in others, while not having the appropriate basis for the movement of the labor market, structural changes therein. It should be noted that the presence and significant influence of psychological factors are not on-

Source: Developed by the authors on the basis of Український центр оцінювання якості освіти [Ukrainskyi tsentr otsiniuvania yakosti osvity] (n.d.).

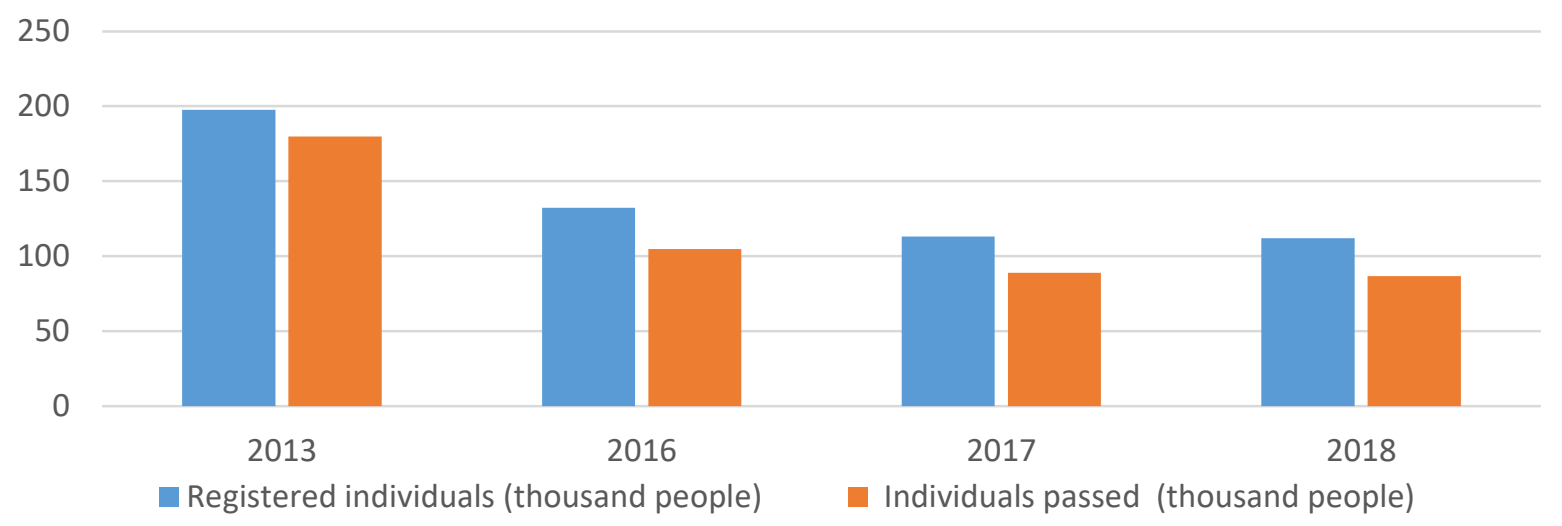

Figure 1. Dynamics of the registration and compilation of EIT in mathematics 
ly characteristic of the subjects of demand in the market of educational services. Researchers quite regularly draw attention to the great importance of these factors, as evidenced, among other things, by the fact that the Taler (2017) received the Nobel Prize in Economics in 2017, which paid considerable attention to the psychological factors of human market behavior (Taler, 2017).

In 2018, the potential physical capacity of the market for higher education in Ukraine (entrance to 1 year of bachelor's level) can be estimated as 335.7 thousand people, of which graduates of secondary schools this year amounted to $55.24 \%$, graduates of previous years $-8.73 \%$, pupils (students) of vocational schools and higher educational establishments 36.03\% (American Marketing Association, n.d.).

The regional segmentation of this market is characterized by the fact that the share of 5 regions ( $20 \%$ of their total) is approximately $40 \%$ in its total potential capacity (Table 2 ).

Table 2. TOP-5 regions of Ukraine by the number of potential entrants in 2018

Source: Developed by the authors on the basis of Український центр оцінювання якості освіти [Ukrainskyi tsentr otsiniuvania yakosti osvity] (n.d.).

\begin{tabular}{l|c|c}
\hline $\begin{array}{c}\text { Region } \\
\text { of Ukraine }\end{array}$ & $\begin{array}{c}\text { Number } \\
\text { of potential } \\
\text { entrants }\end{array}$ & $\begin{array}{c}\text { The proportion to } \\
\text { the total amount of } \\
\text { potential entrants, } \\
\%\end{array}$ \\
\hline $\begin{array}{l}\text { Kyiv and Kyiv } \\
\text { region }\end{array}$ & $41,404(28,432)$ & $12.33(8.47)$ \\
\hline $\begin{array}{l}\text { Dnipropetrovsk } \\
\text { region }\end{array}$ & 24800 & 7.39 \\
\hline Lviv region & 21393 & 6.37 \\
\hline Kharkiv region & 21251 & 6.33 \\
\hline Odesa region & 20653 & 6.15 \\
\hline Ukraine, total & 335687 & 100 \\
\hline
\end{tabular}

Note: Number of potential entrants is considered as the number of people who registered for participation in the EIT.

Thus, the situation on the market of higher education, the observed trends form a serious challenge for the universities in Ukraine, their managers. Marketing aspect in the management of universities is becoming increasingly important. Further improvement of university management should envisage, firstly, the formation of an appropriate style of managers' thinking, which means focusing on market factors for ensuring the competitiveness of IHE. Secondly, it is a question of increasing the efficiency of using a particular set of marketing tools in the management of universities.
"Classic" set of marketing tools in any market is interaction with consumers through the appropriate construction of trade, pricing, marketing and communication policy. Each of these blocks reflects the general strategic approaches of one or another organization to market activity. Let us consider the specifics of use of these marketing tools by the universities.

\subsection{Trade policy}

The conducted analysis shows that the absolutely dominant component in the range of services of the universities of Ukraine is the offer of higher education services. This means that university administrators focus on the definition (adjustment) of a set of specialties on which studies are conducted at the university. The relevant "product portfolios" of universities in recent years have been constantly expanding. However, for the present time, the use of extensive strategies by universities - due to the increasing number of specialties - is, in our opinion, almost completed. Universities have become quite widely universal institutions of higher education in Ukraine. At the same time, they did not always succeed in achieving the required financial result for the new specialties introduced - both in terms of the general level of income and in terms of ensuring the profitability. It became clear that not always opening a new specialty leads to the financial success of a new product, both in the short and long term. The negative point for universities is that the provision of unprofitable services will last for four years (bachelor's cycle). As for others, not directly related to the provision of higher education services, the "product lines" of universities, they remain openly secondary in their financial sense. Probably, for the absolute majority of Ukrainian universities, the absolutely dominant role of higher education services in their income structure will be typical and financially determinative in the near future. Perhaps there will be a gradual increase in the role of foreign students in the formation of the contingent of university students in Ukraine (currently, the share of foreign students is within 5\%).

The question of the expediency of opening a particular specialty in IHE, that is, entering a new market segment, is rather difficult for analytical work within the university. Managers of universities can be suggested to rely on those approaches to the assessment of segments that are recommended to use in "usual" 
business activities, that is, to focus on two groups of assessments: "look in the window" (assessment of the environment, assessment of market factors) and "look in the mirror" (assessment of the internal environment, assessment of their own capabilities) (Yu. Petrunia \& V. Petrunia, 2016). "Look in a mirror" for IHE managers in Ukraine is transformed first and foremost into an assessment of the ability of the university to obtain a license from the Ministry of Education and Science of Ukraine for the opening of the corresponding specialty. "Look in the window" seems to be much more complex, because there is clearly a lack of tools and resources to obtain sufficient and qualitative analytical information on the possible behavior of entrants. Probably the quality of this analytical work could be increased by attracting external research organizations, but Ukrainian universities do not have the appropriate resources for this.

\subsection{Price policy}

In the general business management practice, a fairly wide range of pricing strategies is used. This is not observed in the activity of Ukrainian universities. In most cases, considering the orienta- tion towards the strategy of survival, the universities use the policy of "price caution", the policy of targeting the pricing of competitors. Moreover, it seems that certain IHE form prices for their educational services without sufficient consideration of profitability requirements. That is, in general, the pricing system is relatively simple, focused primarily on the provision of contingent students. In the upper price segment, just a small number of IHE operate.

Let us illustrate the situation on the example of the pricing policy of IHE of Dnipropetrovsk region, which takes the 2nd place in Ukraine by the number of entrants (the region's share is $7.4 \%$ ). In $2018,8.5$ thousand people were admitted to the institution of higher education of Dnipropetrovsk region on a contract basis. The total market share of four universities (Alfred Nobel University, National Technical University "Dnipro Polytechnic", University of Customs and Finance, Dnipro State University of Internal Affairs) - which is $20 \%$ of their total number in the region - made up 55\%. The last figure indicates the signs of the emergence of a regional competition of oligopolistic type.

Source: Compiled by authors on the basis of primary data of universities

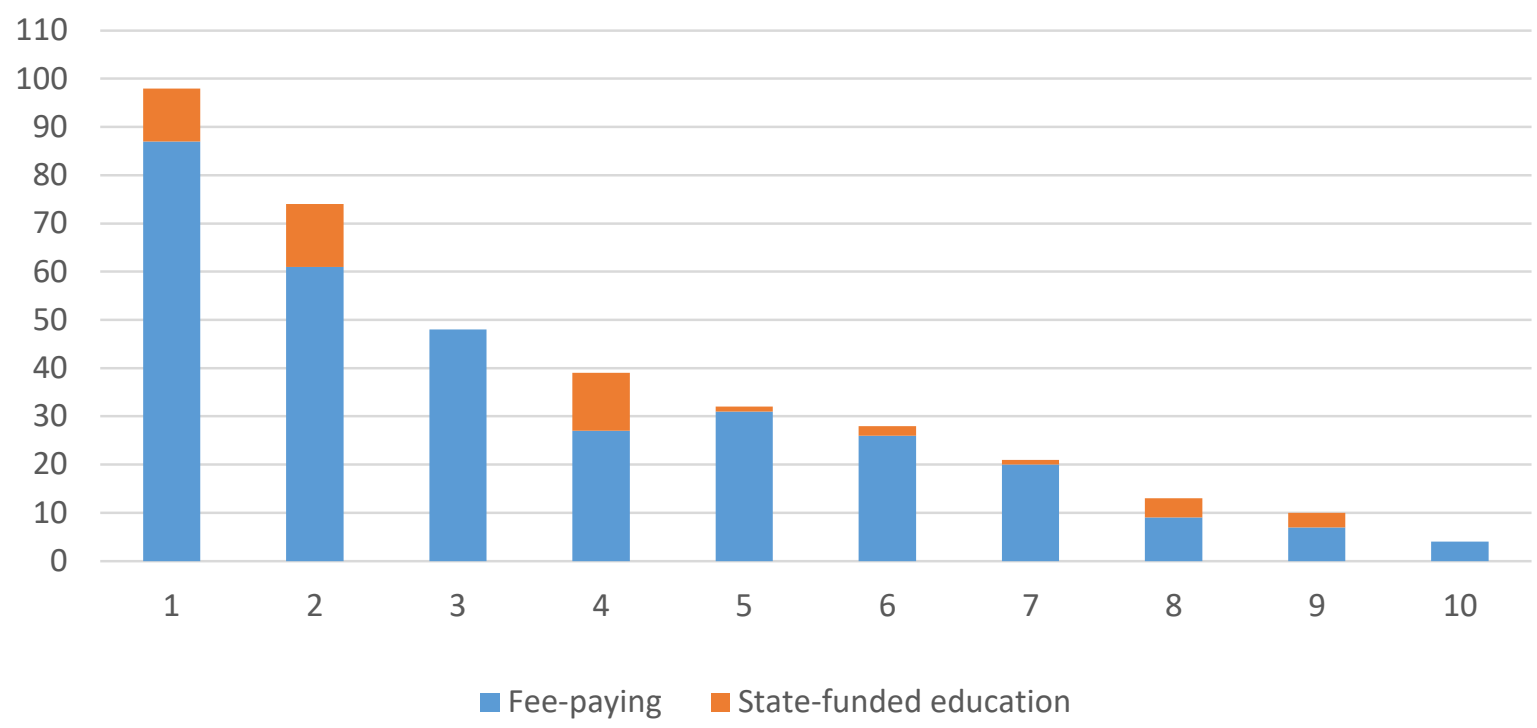

Notes: Symbols: 1 - University of Customs and Finance; 2 - National Technical University "Dnipro Polytechnic"; 3 - University of Alfred Nobel; 4 - Oles Honchar Dnipro National University; 5 - National Metallurgical Academy of Ukraine; 6 - Dnipropetrovsk State Agrarian and Economic University; 7 - Ukrainian State Chemical Technology University; 8 - Prydniprovsk State Academy of Civil Engineering and Architecture; 9 - Dnipropetrovsk National University of Railway Transport; 10 - Dnipropetrovsk Regional Institute of Public Administration.

Figure 2. Number of enrolled in IHE of Dnipro in the specialty "Management" (undergraduate, full-time, 2018) 


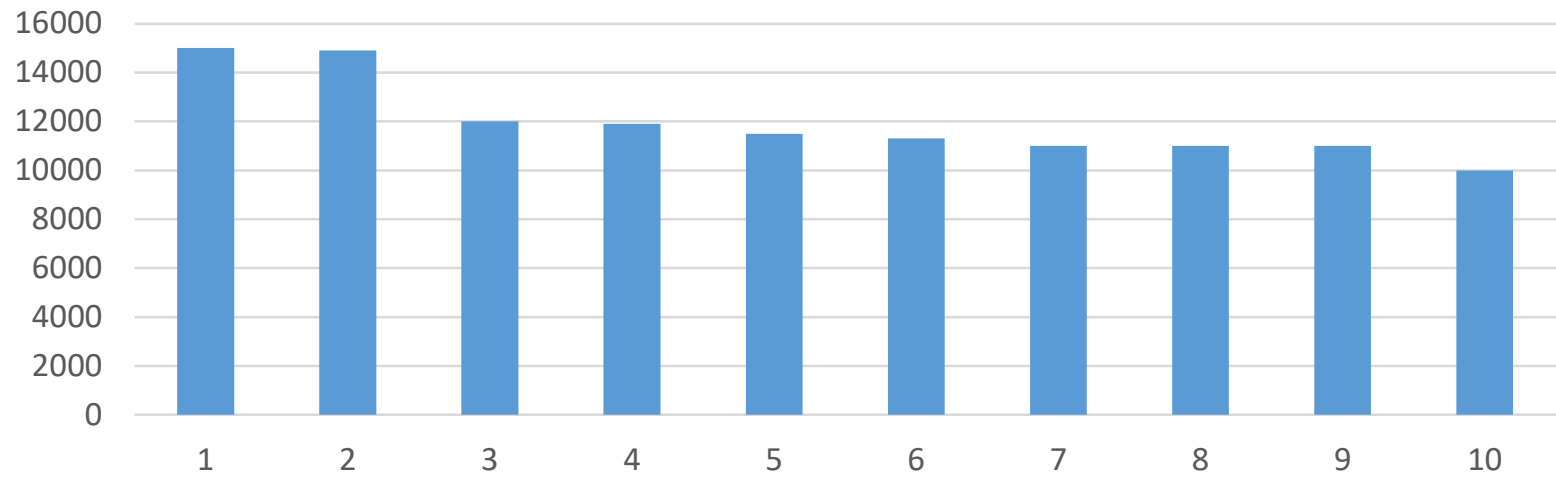

Notes: Symbols: 1 - Oles Honchar Dnipro National University; 2 - University of Alfred Nobel; 3 - Dnipropetrovsk Regional Institute of Public Administration; 4 - Dnipropetrovsk State Agrarian and Economic University; 5 - University of Customs and Finance; 6 - Ukrainian State University of Chemical Technology; 7 - National Technical University "Dnipro Polytechnic"; 8 Dnipropetrovsk National University of Railway Transport; 9 - National Metallurgical Academy of Ukraine; 10 - Prydniprovsk State Academy of Civil Engineering and Architecture.

Figure 3. The cost of one-year study on the specialty "Management" in IHE of Dnipro (undergraduate, full time, year 2018, UAH)

To illustrate the price competition among the universities of Dnipropetrovsk region, we analyzed the example of the recruitment of students for the first year and the pricing policy of the institutions of higher education in the specialty "Management" in 2018. The set of students in the institutions of higher education of Dnipro city in this specialty (Figure 2) ranged from 98 persons (maximum) to 4 people (minimum). In the total number of enrolled for this specialty, the share of the budget order was $11.4 \%$ (in $2017-13 \%$ ), contract places $-88.6 \%$. If to include in the analysis literally all IHE that carried out the recruitment on the given specialty in the specified geographical market (Dnipro city), then we will get the physical capacity of this segment of the market of about 400 people. If we try to estimate the financial capacity of this segment of the market, it will be, according to our estimates, about 4 million UAH.

Figure 3 reflects the cost of one-year study on the specialty "Management" in IHE of Dnipro in 2018. Calculations show that the coefficient of differentiation of the cost of training (the ratio of the highest value to the smallest) is 1.5. In 2017, this coefficient equaled 1.58 , that is, it practically did not change. Thus, firstly, there is a relatively low price differentiation of market proposals of competing entities. Secondly, with the exception of two universities, all competitors are in the closest price range (the view of the diagram is almost a horizontal line). As for the estimation of the elastici- ty of demand for the price, then, between the cost of 15,000 UAH (the highest) and 10,000 UAH (the lowest), it will surely be sufficiently obvious, but with regard to the range of other price proposals (between 10,500 and 12,000 UAH), then, it is unlikely that it will be more or less significant. This situation is generally quite characteristic of the price competition of universities in the context of other specialties and other regional markets.

\subsection{Positioning and marketing communications}

The analysis shows that universities in Ukraine, as a rule, do not pay enough attention to the issue of positioning, or actually ignore it. It does not meet the current standards of market management organizations. It is known that an important prerequisite for the achievement of their goals in a competitive environment is at least a consumer's presentation of features, distinctive qualities of their goods and services. As for higher education in Ukraine, in many cases, we observe what, in our opinion, can be called the option of "non-public positioning for the price".

The uncertainty of the position in the minds of entrants and their parents about differences in the provision of educational services to a particular university is its problem. Although, it must be admitted that the search for a positioning strategy for a university is perhaps a thinner and more 
complex work than a regular business organization. Great restrictive influence on the choice of positioning strategy can be inertia and conservative, which are objectively inherent in the institution of higher education in general. However, the market situation in the field of higher education in Ukraine develops in such a way that universities need to demonstrate to consumers the particularities, advantages of their offer ("its face") - real, understandable and important for entrants and their parents. In a situation where a significant part of the university is experiencing severe financial constraints, it may seem that the question of positioning is not on time. However, universities must have strategies for action, even if "market survival" is to be achieved, a quality strategy is needed, and a vision is needed. Positioning is one of the key components of a strategy, because positioning reflects the vision of the university managers of its competitive advantages over market competitors.

Universities can use different platforms for positioning. For some universities, for example, their age, their history is an important element of their image, their perception by consumers of educational services. The researches fairly pay attention to role of "historical factor" in the psychology of perception consumers of a particular brand (product, organization). The names of long-standing universities are widely known for consumers, and many people from the "circle of communication" of university entrants received education in such universities. For "relatively young" institutions of higher educational, emphasis should probably be somewhat different, which should also be reflected in the corresponding filling of the external communication process. At the same time, it is important that these were systematic, consistent, longterm actions. As Traut and Rays (2006) note, "positioning is the concept of cumulative property".

Thus, nowadays the universities need to develop their marketing management systems to achieve current and strategic competitiveness. Probably, it becomes increasingly obvious that there is a need for a special marketing unit in the university's management structure. Its qualitative work will help the university to move faster from the traditional "vocational guidance work" to a more modern marketing-oriented system of activity and management.
Universities have a fairly conservative governance structure. In general, they are characterized by a linear-functional management model. The marketing unit is a kind of staff unit, its manager should be subject, under the managerial logic, the first vice-rector of the university. How will the linear-head communication form (the relationship of the marketing unit with other structural units) depends, first of all, on what functions will be assigned to the marketing unit, what will be its internal structure, how the functional powers of others will change the subdivisions.

The main functions of the head of the marketing unit are reasonable to recognize the organization of the unit's work, the development of marketing plans for universities, the development of marketing budgets, the implementation of marketing plans, the provision of proposals to the leadership of the university to improve the marketing activities of the university as a whole.

It is expedient to structure the functions of the marketing department of higher educational institutions in two sectors: informational and analytical and marketing communications (PR activities). The spectrum of the functions of the informational and analytical direction is aimed at ensuring the fulfillment of two main tasks: the formation of the necessary information on the state of the marketing environment of the university (entrants, universities-competitors, organizations-employers, etc.) and its internal environment (students, teachers, employees); the formation of proposals for improving the activities of universities, in particular regarding its strategy, positioning, product, price, training and other activities. The spectrum of tasks in the marketing communications sector may include: informing target and contact audiences about educational services of higher educational institutions (creation of advertising products, university site administration, work in social networks, public relations, personal appeals, etc.); bringing to the target and contact audiences the advantages of the university, the conviction of the target audience in the expediency of using the services of higher educational institutions; organizing the days of the entrant and other events, developing and promoting the introduction of "corporate (university)" style (logo, registration of houses, premises, attributes, etc.); work with the business 
environment and other employers, support for contacts with graduates.

\subsection{Use of marketing tools by Polish universities}

Reforming the system of higher education in Ukraine, in particular the introduction and application of marketing tools in the management of universities, should be based on the experience of European countries that have begun a similar process much earlier and already have certain results. Considering mistakes and successes of neighboring countries, Ukraine can successfully use the appropriate principles and methods of management in higher education. Such experience for our country may be the experience of the Polish republic, which is the first post-socialist country to sign the Bologna Declaration in 1999.

In the middle 90 s of the 20th century, the Center for Educational Research and Innovation (CERI), acting within the framework of the Organization for Economic Cooperation and Development (OECD), recommended that the Polish public education leadership develop state education standards, change the criteria for determining competences, potential opportunities and individual peculiarities of Polish schools. The wide-ranging reform of the education system in Poland covered the entire structure of the education system, the substantive aspects of learning, the marketing and management system, quality control and assessment of competences, knowledge and skills. During the last decade, the system of higher education in Poland is developing dynamically. Today, the number of universities is about 500 (of which $2 / 3$ are private and $1 / 3$ are state universities).

The system of higher education in Poland is threetiered. It includes programs offered by state and non-state universities of the university (uczelniaakademicka) and non-university type (uczelniazawodowa), namely:

- first cycle programs, lasting from 3 to 4 years, after their completion, a bachelor's degree is given (licencjat or inżynier, depending on the field of study); second cycle programs lasting 1.5-2 years, after graduation, a master's degree (magister) (or an equivalent degree, depending on the field of study);

- programs of the third cycle or doctoral programs lasting from 3 to 4 years are offered only by universities of the university type.

Graduates from the universities of Poland can receive the following educational qualification levels:

Bachelor (BA, licencjat) - the degree that colleges' and universities' students receive after completing a 3.5-year course.

- Bachelor (BSc, inzynier) - the degree that students from universities and colleges graduate from for 3.5-4 years in economic, technical or agricultural specialties.

- Master (MA, MSc, Magister) - a degree that is given to doctors, veterinarians, dental surgeons, engineers, architects, art historians who have completed their studies at a university aged 5-6 years. Bachelors have the opportunity to obtain a master's degree after additional training duration of 2-2.5 years.

- Doctor of Science (Ph.D, doctor) - a degree that is awarded to scientists who defended their doctoral dissertation and passed exams in the corresponding specialty. Before completing doctoral studies, you must first obtain a master's degree.

Considering marketing tools, Polish universities use their traditional set, focusing on interaction with consumers of educational services through appropriate trade, price and communication policies. At the same time, the system of higher education in Poland is more prone to international trends related to the strengthening of the marketing orientation of university education.

Among the priority, strategic directions of higher education development in Poland, where the main financial resources of the state are concentrated, sustainable development of transport infrastructure, agriculture, energy, ecological and national security can be singled out. However, 
currently they are not among the most popular areas of professional training for students. The first places in the ranking of specialties of Polish institutions of higher education are economy and management, sociology, pedagogy and medicine.

Regarding price policy, by the end of 2018, it is approximately as follows:

- studying at a private institution of higher education - from 800 euro per year;

- studying at a state institution of higher education - from 2,000 euro per year;

- $\quad$ studying for foreigners on the competitive basis - free;

- studying for those who have "Karta Polaka" - free.

Besides, pricing policy is different in state and private universities. For example, let's compare prices for educational services of two Warsaw universities. Thus, in particular, the well-known and prestigious Warsaw State University offers a Bachelor's degree, studying in Polish, with payment from 2,000 to 5,200 euros per year, depending on the specialty. At the same time, the well-known private Finance and Business Academy Vistula provides an opportunity to study under a Bachelor's program with a payment of from 1300 to 1450 euros per year.

A lot of attention in the system of the European education is paid to the practical training and employment of students. Universities of Poland actively cooperate with educational institutions from other countries, students have the opportunity to train and study in other universities of the European Union and the world. At the same time, Polish state and private universities cooperate with international companies and effectively promote their students on the territory of Poland.

In general, the current results of the higher education system in Poland functioning are not at the highest international level, but the pace of development, the volume of investments at all levels of education, its availability and support of the EU can predict a successful solution to the strategic challenges posed to Polish education.

\section{CONCLUSION}

The state of higher education in Ukraine is characterized by the tendencies of worsening of a number of key indicators, which forms a threat to universities and negatively affects the market capacity. The current dominance of the marketing environment of the universities in Ukraine is the change in the state distribution of budget places between IHE, adjusting the impact of the system of EIT on the formation of segments of demand in specialties, the intensification of the competition between IHE, with particular emphasis on price methods of competition. The distribution of public funding between universities on the basis of individual outcomes of EIT has significant disadvantages in social and regional terms. The dominant marketing trade policy of IHE in recent years is the expansion of the "portfolio of specialties", but currently the possibilities of such strategies are practically exhausted. The dominant price policy is focusing on a price strategy for survival. A large number of universities are trying to compete at the expense of "cautious price policy". The positioning of higher educational institutions in many cases is common, which is a sign of insufficient strategic certainty. The development of marketing management at universities is essential for further ensuring their market competitiveness. One of the areas is to improve the line-functional model of university's management by significantly enhancing its marketing organizational structure with such main groups of functions as information-analytical and marketing-communicational. The authors indicate that the reform of the higher education system in Ukraine, including the use of marketing tools in the management of universities, shouldbe based on the experience of European countries, Poland in particular. 


\section{REFERENCES}

1. Agyemang, G., \& Broadbent, J. (2015). Management control systems and research management in universities: An empirical and conceptual exploration. Accounting, Auditing \& Accountability Journal, 28(7), 1018-1046. https://doi. org/10.1108/AAAJ-11-2013-1531

2. Aithal, P. S., \& Aithal, S. (2016). Impact of On-line Education on Higher Education System. International Journal of Engineering Research and Modern Education (IJERME), 1(1), 225-235. http://doi. org/10.5281/zenodo.161113

3. American Marketing Association (n.d.). Events and conferences. Retrieved from http://www.ama. org/events-training/conferences/ page/2019

4. Babichev, A. V. (2017). Зарубіжний досвід із питань управління змінами в системі вищої освіти [Zarubizhnyi dosvid iz pytan upravlinnia zminamy v systemi vyshchoi osvity]. Teoriia ta praktyka derzhavnoho upravlinnia, 2, 1-9.

5. Bouen, W. (2018). Bыcmee образование в иифровую эпоху [Vysshee obrazovanie $v$ tsifrovuyu epokhu] (224 p.). Moscow: Izdatelskiy dom Vysshey shkoly ekonomiki.

6. European Foundation for Management Development (n.d.) Strategic partners. Retrieved from https://efmdglobal.org/about-us/ strategic-partners

7. Hall, H. (2007). Marketing w szkolnictwie (236 p.). Warszawa: Wolters Klumer Polska Sp. Z o.o.

8. Kollini, S. (2016). Зачем нужны университеть?? [Zachem nuzhny universitety?] (264 p.). Moscow: Izdatelskiy dom Vysshey shkoly ekonomiki.

9. Kudła, J., Stachowiak-Kudła, M., Polszakiewicz, B., Boehlke, J. (Eds.). (2014). The higher education competition in Poland and the quality of teaching and research: the case of economic and law studies. Ekonomia i Prawo. Economics and Law, 13(4), 471-482. http://dx.doi. org/10.12775/EiP.2014.033

10. Kwiek, M. (2013, August). From System Expansion to System
Contraction: Access to Higher Education in Poland. Comparative Education Review, 57(3), 553576. Special Issue on Fair Access to Higher Education. https://doi. org/10.1086/670662

11. Manea, N., \& Purcaru, M. (2017). The evolution of educational marketing. Annals of Spiru Haret University, Economic Series, 17(4). https://doi.org/10.26458/1744

12. Mohylova, A. Yu., \& Reshetnykova, I. V. (2016). Особливості маркетингу на ринку освітніх послуг [Osoblyvosti marketynhu na rynku osvitnikh posluh]. Naukovyi visnyk Uzhhorodskoho natsionalnoho universytetu. Seriia "Mizhnarodni ekonomichni vidnosyny ta svitove hospodarstvo", 10(2), 21-25. Retrieved from https://bit.ly/2FMCUdo

13. Northey, G., Bucic, T., Chylinski, M., Govind, R. (2015). Increasing Student Engagement Using Asynchronous Learning. Journal of Marketing Education, 37(3). https://doi. org/10.1177\%2F0273475315589814

14. Orindaru, A. (2016). Developing Marketing Higher Education Strategies Based on Students Satisfaction Evolution in Time. Romanian Economic Journal, 18(57), 167-182. Retrieved from https:// ideas.repec.org/a/rej/journl/v18y2015i57p167-182.html

15. Petrunia, Yu., \& Petrunia, V. (2016). Маркетинг: навчальний посібник (3-тє вид., переробл. і доповн) [Marketynh: navchalnyi posibnyk (3tie vyd., pererobl. i dopovn.)] (97 p.). Dnipropetrovsk: Universytet mytnoi spravy ta finansiv.

16. Prasad Krishna, K., \& Aithal, P. S. (2017). A Study on Online Education Model using Location Based Adaptive Mobile Learning. International Journal of Applied Engineering \& Management Letters, 1(1), 36-44. http://dx.doi. org/10.5281/zenodo.820457

17. Shah, M., Sid Nair, C., \& Bennett, L. (2013). Factors influencing student choice to study at private higher education in situations. Quality Assurance in Education, 21(4), 402-416. https://doi.org/10.1108/QAE-042012-0019

18. Shevchenko, L. S. (2016). Університетська освіта: економічні пріоритети та управління розвитком: монограбія [Universytetska osvita: ekonomichni priorytety ta upravlinnia rozvytkom: monohrafia] (188 p.). Kharkiv: Pravo. Retrieved from http://dspace.nlu.edu.ua/ handle/123456789/12374

19. Sihaieva, L. Ye. (2017). Зарубіжний досвід управління освітою: основні тенденції [Zarubizhnyi dosvid upravlinnia osvitoiu: osnovni tendentsii]. Visnyk Cherkaskoho universytetu, 10, 106-113.

20. State Statistics Service of Ukraine (2018). Вищз освіта в Украӥні y 2017 році. Статистичний збірник [Vyshcha osvita v Ukraini u 2017 rotsi. Statystychnyi zbirnyk] (298 p.). Kyiv.

21. Taler, R. (2017). Новая поведенческая экономика [Novaya povedencheskaya ekonomika] (540 p.). Moscow: Eksmo.

22. The European University Association (2018). Public Funding Observatory. Retrieved from http:// eua.be/activities-services/projects/ eua-online-tools/public-fundingobservatory-tool.aspx

23. Tienhaara, P., Lyytinen, A., \& Kivistö, J. (2016). Management education in transformation current challenges and future perspectives. University of Tampere. Retrieved from https:// tampub.uta.fi/bitstream/hand le/10024/99665/978-952-03-0211-5. pdf? sequence $=1$

24. Traut, G. (2006). Дифференцируйся или умирай! [Differentsiruysya ili umiray!] (transl. from English) (129 p.). Saint Petersburg: Piter.

25. Traut, G., \& Ries, $\mathrm{Al}$ (2006). Позиционирование: битва за умы [Pozitsionirovanie: bitva za umy] (transl. from English) (245 p.). Saint Petersburg: Piter.

26. Український центр оцінювання якості освіти [Ukrainskyi tsentr otsiniuvania yakosti osvity] (n.d.). Дослідження та аналітика [Doslidzhennia ta analityka]. Retrieved from http://www.testportal. gov.ua 